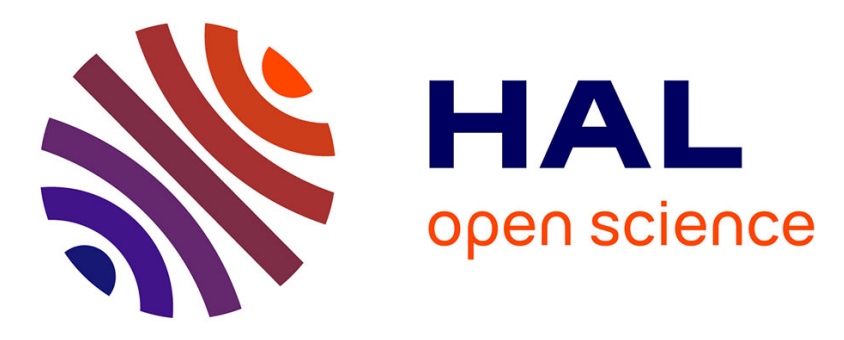

\title{
Geographic distribution of anti-Leptospira antibodies in humans in Côte d'Ivoire, West Africa
}

Stephane Kouadio Koffi, Syndou Meite, Abdoulaye Ouattara, Stephane Kan Kouassi, Sylla Aboubacar, Veronique Agbaya Akran, Pascale Bourhy, Mireille Dosso

\section{To cite this version:}

Stephane Kouadio Koffi, Syndou Meite, Abdoulaye Ouattara, Stephane Kan Kouassi, Sylla Aboubacar, et al.. Geographic distribution of anti-Leptospira antibodies in humans in Côte d'Ivoire, West Africa. European Journal of Clinical Microbiology and Infectious Diseases, 2018, 37 (11), pp.2177-2180. 10.1007/s10096-018-3359-7 . pasteur-03251358

\section{HAL Id: pasteur-03251358}

https://hal-pasteur.archives-ouvertes.fr/pasteur-03251358

Submitted on 7 Jun 2021

HAL is a multi-disciplinary open access archive for the deposit and dissemination of scientific research documents, whether they are published or not. The documents may come from teaching and research institutions in France or abroad, or from public or private research centers.
L'archive ouverte pluridisciplinaire HAL, est destinée au dépôt et à la diffusion de documents scientifiques de niveau recherche, publiés ou non, émanant des établissements d'enseignement et de recherche français ou étrangers, des laboratoires publics ou privés. 
1 Geographic distribution of anti-Leptospira antibodies in humans in Côte 2 d'Ivoire, West Africa.

4 Koffi Kouadio Stephane ${ }^{1,2}$, Meite Syndou ${ }^{1}$, Ouattara Abdoulaye ${ }^{1}$, Kouassi Kan Stephane ${ }^{1}$, Sylla 5 Aboubacar $^{1}$, Akran Agbaya Veronique ${ }^{1}$, Bourhy Pascale ${ }^{3}$, Dosso Mireille ${ }^{1}$.

61 : Institut Pasteur de Côte d'Ivoire

72 : UFR Sciences médicales Université F. Houphouët-Boigny/CHU de Cocody

83 : Centre National de Référence de la leptospirose, Institut Pasteur de Paris

Corresponding author

11 KOFFI Kouadio Stéphane

1208 BP 919 Abidjan 08

13 Tel: (225) 05788663

14 Koffi.ks@gmail.com 


\section{INTRODUCTION}

Leptospirosis is a zoonotic bacterial disease with a worldwide distribution caused by pathogenic bacteria of the genus Leptospira [1]. It is an endemic disease especially in subtropical and tropical regions and outbreaks can occur after heavy rain or flooding [1]. Transmission occurs through direct or indirect contact with urine of infected animals [1,2].

Leptospirosis may be unrecognized or misdiagnosed because of the lack of specific clinical symptoms, thus human incidence is commonly underreported.

The World Health Organization (WHO) Leptospirosis Epidemiology Reference Group (LERG) estimated the leptospirosis incidence at 1.03 million cases and 58,900 deaths each year worldwide [3]. West African annual leptospirosis incidence was estimated to be 9.7 per 100,000 population [3]. In West Africa, few studies on Leptospira prevalence have been published. And prevalence of acute human leptospirosis ranged from $0.0 \%$ to $7.8 \%$ in five studies on symptomatic patients [4,5].

In Côte d'Ivoire, data are sparse, however an unpublished study carried out in 2013 by the "Centre Suisse de Recherche Scientifique" in Yopougon (Abidjan) showed, 4\% prevalence in both 124 febrile patients and 99 rodents using MAT showing human and animal infection. Another study showed high prevalence in 93 vaccinated dogs (58\%) and 63 non-vaccinated dogs (47\%) sampled in Abidjan and in two neighbouring cities using MAT suggesting human exposure [6].

Thus, little is known about leptospirosis in the country and data are needed to inform burden estimates and to inform intervention strategies. Mapping leptospirosis exposure could help find high-risk areas and lead intervention choices against the disease. This study aims to determine the geographic distribution of anti-Leptospira antibodies in humans in Côte d'Ivoire.

\section{MATERIAL AND METHODS}

This study was carried out from August to November 2015 in the 82 health districts of Côte d'Ivoire. The study was carry out on stored human specimens previously collected for the national surveillance system for communicable diseases in 2014. Only negative specimens were included in the study.

One to 13 serum samples were randomly selected per health district based on the number of notified cases by health districts in the year to obtain a sample size of 384 .

Blood samples were collected from each patient who matches the clinical WHO's case definition for notifiable disease. Samples were sent, at $+4^{\circ} \mathrm{C}$, to the National Reference Centre at the Institut Pasteur de Côte d'Ivoire for analysis. Anti-Leptospira antibody testing was carried out at Institut Pasteur de Côte d'Ivoire (IPCI) and Institut Pasteur in Paris (IP). We used as screening methods the ELISA against type IgG anti-Leptospira antibodies previously describe by Bourhy et al. (2013) in IPCI [7]. Confirmation was carried out by MAT in IP with a threshold of 1:50. As antigens, 16 serogroups were used (table 1).

Socio-demographic and clinical data from the National Reference Centre, which manage the samples and results for analysis performed on studied samples, were used to build a database using Epi Info software (CDC, Atlanta, Georgia). Data analyses were done using R software 3.2.0 [8].

\section{RESULTS}

Age of patients ranged from 1 month to 78 years old with a mean age of 20.8 years. Patients less than 25 years were more represented with $60.9 \%$ of all patients. We noted a male predominance with a sex ratio of 1.55 .

Of the samples tested, ELISA positively screened 90 . Of these, 36 were confirmed by MAT representing $9.4 \%$ prevalence. People with anti-Leptospira antibodies had a mean age of 34.5 years and a Sex ratio of 2. Of the 82 health districts of the country, anti-Leptospira antibodies were found in samples from 22. Health districts with anti-Leptospira antibodies were mostly located in the western and the southern parts of the country (fig 1).

MAT anti-Leptospira antibodies titre ranged from 1:50 to 1:6400. Eight different serogroups of Leptospira were found (table 2). Serogroup Panama was the most frequent $(36.1 \%)$ followed by Louisiana (19.4\%) and Grippotyphosa and Sejroe (11.1\% respectively). 


\section{DISCUSSION}

This study focuses on anti-Leptospira antibodies in human specimens collected in the national surveillance system for communicable diseases in Côte d'Ivoire. Few published data on Leptospira and leptospirosis in Côte d'Ivoire are available [4, 5, 9]. Our study, which focus on type IgG antibodies showed a prevalence of $9.4 \%$. This result is in accordance with the LERG who estimated an annual incidence for leptospirosis to $9.6 \%$ in the West sub-Saharan Africa WHO region [3].

Samples from all the 82 health districts of the country were included in this study. So, the studied population were representative of all the country. However, health districts with anti-Leptospira antibodies found in this study were mostly located in the western and the southern parts of the country (fig 1). These parts of the country are peculiar by their climate and forest cover. They are the most humid parts of the country with higher forest cover and heavy raining season compare to the northern part of the country, which is mostly arid. It's actually well known that leptospirosis is related to water and wet soils were Leptospira find proper conditions for his maintenance in the environment [10, 11, 12]. In these parts of the country, some irrigated farming activities like rice, banana and vegetable farming are associated with risk behaviours like walking barefooted in wet farm soil, sludge or working without wearing appropriated personal protective equipment. The maintenance of Leptospira in the environment is better when bacteria are protected from direct UV sunlight [13]. This situation could be achieved in forests or in large farms with trees like cocoa, coffee or rubber plantations mostly seen in the western and southern part of the country. These plantations also offer habitats to small mammals that are considered a reservoir of bacteria and create a Human/ Animal/ Environment interface, which could improve the transmission of the disease.

Regarding people with anti-Leptospira antibodies, they were young adults (mean age 34.5 years) mostly men (sex ratio 2) living in rural area; corresponding to active low-income farmers working into agricultural fields. These people could represent an at-risk population and it could be suitable to implement prevention activities against leptospirosis related to them. Indeed, farming is a major activity in Côte d'Ivoire representing $43.5 \%$ of jobs.

This study highlights the circulation of leptospirosis among people in Côte d'Ivoire. Unfortunately, no routine laboratory-based diagnostic strategies are available for leptospirosis or other diseases such as rickettsia or viral hepatitis. Numerous patients suffering from infectious diseases are not correctly diagnosed, and the burden of these diseases is underestimated. Early diagnosis and treatment reduce occurrence of complications and improve recovery rate significantly [1]. There is a need to improve public health by Ivorian authorities and their international partners.

\section{COMPLIANCE WITH ETHICAL STANDARDS}

Funding: No funding was received.

Conflict of Interest: The authors declare that they have no conflict of interest.

Ethical approval: The national ethic and research committee of Côte d'Ivoire approved this study under the number 23/MSLS/CNER-dkn.

Informed consent: Not applicable.

\section{REFERENCES}

1. Haake DA, Levett PN (2015) Leptospirosis in humans. Curr Top Microbiol Immunol 387:65-97. doi: 10.1007/978-3-662-45059-8_5.

2. Hartskeerl RA, Collares-Pereira M, Ellis WA (2011) Emergence, control and re-emerging leptospirosis: dynamics of infection in the changing world. Clinical Microbiology and Infection 17:494-501. doi: 10.1111/j.1469-0691.2011.03474.x.

3. Costa F, Hagan JE, Calcagno J, Kane M, Torgerson P, Martinez-Silveira MS, Stein C, AbelaRidder B, Ko AI. (2015) Global Morbidity and Mortality of Leptospirosis: A Systematic Review. PLoS Negl Trop Dis 9: e0003898. doi: 10.1371/journal.pntd.0003898.

4. De Vries SG, Visser BJ, Nagel IM, Goris MG, Hartskeerl RA, Grobusch MP (2014) Leptospirosis in Sub-Saharan Africa: a systematic review. Int J Infect Dis 28:47-64. 
5. Allan KJ, Biggs HM, Halliday JEB, Kazwala RR, Maro VP, Cleaveland S, Crump JA. (2015) Epidemiology of Leptospirosis in Africa: A Systematic Review of a Neglected Zoonosis and a Paradigm for 'One Health' in Africa. Plos Neglected Tropical Diseases 9: 3899-3899.

\section{FIGURE CAPTIONS}

Fig 1 shows health districts were people with anti-Leptospira antibodies were found. Colors are related 140 